University of Nebraska - Lincoln

DigitalCommons@University of Nebraska - Lincoln

Sex Steroid and Thyroid Hormone Receptor Expressions in the Thyroid of the American Alligator (ALLIGATOR MISSISSIPPIENSIS) During Different Life Stages

\author{
Dieldrich S. Bermudez \\ USEPA, dieldrich@gmail.com \\ Jeremy P. Skotko \\ University of Florida \\ Yasuhiko Ohta \\ Tottori University \\ Ashley S.P. Boggs \\ University of Florida \\ Taisen Iguchi \\ National Institutes of Natural Sciences \\ See next page for additional authors \\ Follow this and additional works at: https://digitalcommons.unl.edu/usepapapers \\ Part of the Civil and Environmental Engineering Commons
}

Bermudez, Dieldrich S.; Skotko, Jeremy P.; Ohta, Yasuhiko; Boggs, Ashley S.P.; Iguchi, Taisen; and Guillette, Louis J. Jr., "Sex Steroid and Thyroid Hormone Receptor Expressions in the Thyroid of the American Alligator (ALLIGATOR MISSISSIPPIENSIS) During Different Life Stages" (2011). U.S. Environmental Protection Agency Papers. 80.

https://digitalcommons.unl.edu/usepapapers/80

This Article is brought to you for free and open access by the U.S. Environmental Protection Agency at DigitalCommons@University of Nebraska - Lincoln. It has been accepted for inclusion in U.S. Environmental Protection Agency Papers by an authorized administrator of DigitalCommons@University of Nebraska - Lincoln. 
Authors

Dieldrich S. Bermudez, Jeremy P. Skotko, Yasuhiko Ohta, Ashley S.P. Boggs, Taisen Iguchi, and Louis J. Guillette Jr. 


\title{
Sex Steroid and Thyroid Hormone Receptor Expressions in the Thyroid of the American Alligator (ALLIGATOR MISSISSIPPIENSIS) During Different Life Stages
}

\author{
Dieldrich S. Bermudez, ${ }^{1,2 \star}$ Jeremy P. Skotko, ${ }^{1}$ Yasuhiko Ohta, ${ }^{3}$ Ashley S.P. Boggs, ${ }^{1}$ \\ Taisen Iguchi, ${ }^{4,5}$ and Louis J. Guillette Jr. ${ }^{1,6,7}$ \\ ${ }^{1}$ Department of Biology, 220 Bartram Hall, University of Florida, Gainesville, FL 32611 \\ ${ }^{2}$ US EPA, NHEERL, TAD, MD-72 Research Triangle Park, NC 27711 \\ ${ }^{3}$ Laboratory of Experimental Animals, Department of Veterinary Medicine, Faculty of Agriculture, \\ Tottori University, Tottori 680-8553, Japan \\ ${ }^{4}$ Okazaki Institute for Integrative Bioscience, National Institute for Basic Biology, \\ National Institutes of Natural Sciences, Okazaki 444-8787, Japan \\ ${ }^{5}$ Department of Basic Biology, The Graduate University for Advanced Studies (SOKENDAI), \\ Okazaki 444-8787, Japan \\ ${ }^{6}$ Department of Obstetrics and Gynecology, Medical University of South Carolina, Charleston, SC 29425-6190 \\ ${ }^{7}$ Hollings Marine Laboratory, 331 Ft. Johnson Rd, Charleston, SC 29412
}

ABSTRACT The expression of estrogen receptors, $\operatorname{ESR} 1(\mathrm{ER} \alpha)$ and $\mathrm{ESR} 2(\mathrm{ER} \beta)$, and androgen receptors $(\mathrm{AR})$ in the thyroid gland has been reported in few vertebrate species other than a few mammals. This study reports the presence of sex steroid hormone receptors and thyroid receptors (ER $\alpha, \mathrm{ER} \beta, \mathrm{AR}, \mathrm{TR} \alpha$, and $\mathrm{TR} \beta)$ in the thyroid gland of the American alligator at several life stages. It provides a semiquantification and distribution of ER $\alpha$ in the thyroid follicle cells using an immunohistochemical approach as well as reports quantitative differences in mRNA expression of $\mathrm{ER} \alpha, \mathrm{ER} \beta, \mathrm{TR} \alpha$, $\mathrm{TR} \beta$, and $\mathrm{AR}$ in the same tissue using quantitative real time-PCR (Q-PCR) with primers designed specifically for alligators. The thyroid tissue of the American alligator expresses $\mathrm{ER} \alpha, \mathrm{ER} \beta$, and $\mathrm{AR}$ at all of the life stages examined here although no statistically significant differences were observed between male and female in thyroid mRNA expression for any of the genes analyzed. No sexual dimorphism was observed in $\mathrm{ER} \alpha$ immunostaining. No statistical analysis across life stages were performed due to confounding factor of season. J. Morphol. 272:698-703, 2011. (ㅇ 2011 Wiley-Liss, Inc.

KEY WORDS: alligator; $\mathrm{ER} \alpha$; thyroid

\section{INTRODUCTION}

The thyroid and its hormones play essential roles during development and growth of numerous tissues, such as the central nervous system and skeletal system (Styne, 1998; Cayrou et al., 2002; Bernal et al., 2003; Norris, 2007). It has been shown to play various roles in homeostasis, cellular metabolism, and reproduction (Cooke et al., 1991; Arambepola et al., 1998; Norris, 2007). In juvenile American alligators, seasonal variations in plasma thyroxine concentrations parallel seasonal variations in sex steroid concentrations (Bermudez et al., 2005). This pattern suggest that the thyroid axis could have a role in regulating gonadal activity and vice versa. Sex steroid hormone receptors in the thyroid are thought to be of the nuclear super family of receptors, which regulate target gene expression involved in metabolism, development, and reproduction (McKenna and O'Malley, 2001). The role that these sex steroid hormones, and their receptors, play in the regulation of the thyroid is not currently well understood.

The presence of estrogen receptors, ESR1 $(\mathrm{ER} \alpha)$ and ESR2 (ER $\beta$ ), and androgen receptors (AR) in cells of the thyroid has been reported for mammals, namely humans, rats and livestock (Fujimoto et al., 1992; Giani et al., 1993; Madej et al., 2002; Kawabata et al., 2003). In humans, thyroid disorders are more frequently diagnosed in the female compared with the male population (approximately

\footnotetext{
Contract grant sponsor: Ministry of Education, Culture, Sports, Science and Technology (Grants-in-Aid for Scientific Research); Contract grant sponsor: UF Opportunity Fund; Contract grant sponsor: Howard Hughes Medical Institute Professors program; Contract grant sponsor: U.S. NIH; Contract grant number: R21 ES014053-01; Contract grant sponsor: NIEHS Minority Predoctoral Fellowship; Contract grant number: 5F31HD051093-02; Contract grant sponsor: NSF East Asia Summer Institutes Fellowship; Contract grant number: 0513106.
}

*Correspondence to: Dieldrich S Bermudez, US EPA, NHEERL, TAD MD-72, Research Triangle Park, NC 27711.

E-mail: dieldrich@gmail.com

Received 30 July 2010; Revised 8 November 2010;

Accepted 21 November 2010

Published online 9 February 2011 in

Wiley Online Library (wileyonlinelibrary.com)

DOI: 10.1002/jmor.10936 
3:1; Paterson et al., 1999; Manole et al., 2001; Arain et al., 2003; Chen et al., 2008). Further, neoplastic tissues from human thyroid glands express a higher number of ERs when compared with normal tissue (Manole et al., 2001; Chen et al., 2008), suggesting a potential relationship between sex and susceptibility to thyroid abnormalities. Gonadal steroid hormones have been shown to influence thyroid function by altering clearance of thyroxine-binding globulin (TBG), with estrogens increasing serum TBG concentrations and androgens decreasing concentrations of TBG (Tahboub and Arafah, 2009). Testosterone and estradiol upregulated their respective receptors in the thyroids of gonadectomized rats (Banu et al., 2002). These findings suggest that ER signaling could play a significant role in thyroid regulation.

This study describes the presence and distribution of sex steroid hormone (ER $\alpha, \mathrm{ER} \beta$, and $\mathrm{AR})$ and thyroid hormone receptors (TR $\alpha$ and TR $\beta$ ) in the thyroid gland obtained from alligators at several life stages and provides a semiquantification of $\mathrm{ER} \alpha$ protein using an immunohistochemical approach. Quantitative differences in mRNA expression of $\mathrm{ER} \alpha, \mathrm{ER} \beta, \mathrm{TR} \alpha, \mathrm{TR} \beta$, and $\mathrm{AR}$ also were determined in the same tissue using quantitative real time-PCR (Q-PCR) with primers designed specifically for alligators. This study examines the potential sexual dimorphism in hormone receptor expression in the alligator thyroid gland. Because of the presence of both ER $\alpha$ and ER $\beta$ throughout life in the thyroid gland of humans (Kawabata et al., 2003), we hypothesized that other vertebrates, such as alligators, would also express both ERs in the thyroid gland although this has not been documented in any vertebrate other than mammals.

The thyroid gland plays a role in sex steroid hormone regulation, and because hormone production changes with an animal's developmental stages from neonate to adult, it is possible that steroid hormone receptor expression changes with developmental maturity. To investigate whether sex steroid hormone receptor expression changes ontogenically, we examined alligators from neonate, juvenile, and adult life stages.

\section{MATERIALS AND METHODS Animals}

Five male and five female neonatal, juvenile, and adult alligators were collected from Lake Woodruff (latitude $29^{\circ} 06^{\prime} \mathrm{N}$, longitude $81^{\circ} 25^{\prime} \mathrm{W}$ ), Florida, USA. In June of 2003 , the juvenile specimens were captured at night from an airboat by a handrestraint technique. These juvenile American alligators (A. mississippiensis) ranged from $84.6-137.6 \mathrm{~cm}$ in total length with a mean length of $110.2 \mathrm{~cm}$ and were captured between 2100 and $0100 \mathrm{~h}$. On capture, they were sexed and placed in a cloth bag for transport back to the University of Florida where they were euthanized and tissues obtained within $10 \mathrm{~h}$ of initial capture.
In late June 2003, 12 eggs were collected from Lake Woodruff and transported to the University of Florida. Because the sex of alligators is temperature dependent, six eggs were incubated at $33.5^{\circ} \mathrm{C}$, a temperature that generates $100 \%$ males, and six eggs were incubated at $30^{\circ} \mathrm{C}$, the female determining temperature for alligators from central Florida, USA. In mid August, as each egg hatched, the neonate was euthanized and tissues obtained. The neonates ranged from 23.5 to $26 \mathrm{~cm}$ in total length with a mean length of $24.9 \mathrm{~cm}$. In September of 2003, adult alligators were captured at night using a standard noosing technique. The adult alligators ranged from 178 to $333 \mathrm{~cm}$ in total length with a mean length of $225.4 \mathrm{~cm}$ were captured during the $2300-0200 \mathrm{~h}$. The specimens were sexed in the field and transported to the University of Florida where the alligators were euthanized and tissues obtained within $7 \mathrm{~h}$.

Euthanasia was performed by an overdose of sodium pentabarbitol, injected intravenously into the postcranial vertebral vein, a protocol approved by the University of Florida IACUC. Thyroid glands were removed from all specimens and divided into two lobes. One thyroid lobe was preserved in cold Bouin's fixative (fixative was on ice), whereas the other lobe was flash frozen in liquid nitrogen for molecular studies. Additional tissues (gonad, liver, heart, phallus, and brain) were harvested for use in other ongoing studies.

\section{Histological Analysis and Statistics}

Thyroid tissues from each age group were prepared using standard histological techniques. For immunohistochemical analysis of $\mathrm{ER} \alpha$ expression, each animal was represented by a set of slides that consisted of three slides (with multiple tissue sections): one control slide that was not treated with primary antibody, one experimental slide in which tissues were exposed to the primary antibody for $\mathrm{ER} \alpha$, and one normal hemotoxylin and eosin stained slide. Experimental slides were treated using standard immunohistochemistry techniques (Vector Elite ICC kit) and antibodies specific for the AR (C-19, Santa Cruz Technology): sc-815 or ER $\alpha$ (MC-20, Santa Cruz Technology): sc-542.

Once the slides were stained, three intact thyroid follicles were analyzed. The total number of positive stained nuclei from the immunohistochemical slide was divided by the total number of nuclei from the same follicle. These ratio data were then transformed by arcsine conversion for use in statistical analyses. The average for the three follicles was used to represent the relative ER $\alpha$ protein expression in the thyroid gland of each alligator. This technique was used to provide a semiquantification of ER $\alpha$ protein expression levels in the thyroid gland. Comparisons between sexes at each life stage was analyzed using StatView software with a significance $\alpha=0.05$ (version 5.0; SAS Institute, Cary, NC). We had very limited success with AR immunostaining on alligator thyroid follicles. Although the presence of an AR-like protein was localized, staining was never consistent enough with the available antibody so that an analysis could be performed.

\section{Isolation of RNA, Reverse Transcription, and Northern Blots}

Quantitative real time-PCR (Q-PCR) was performed to quantify mRNA expression levels for $\mathrm{ER} \alpha, \mathrm{ER} \beta, \mathrm{AR}, \mathrm{TR} \alpha$, and TR $\beta$ in neonatal, juvenile, and adult thyroid gland tissue. The techniques used were those that we have validated previously for alligator tissues (Katsu et al., 2004; Helbing et al., 2006).

Quantitative real time-PCR was performed using standard techniques. In short, total RNA was isolated with a RNeasy kit (QIAGEN, Chatsworth, CA). First strand cDNA synthesis was performed on $4 \mu \mathrm{g}$ of total RNA using SuperScript II RNase H-Reverse Transcriptase (Invitrogen, Gaithersburg, MD) and oligo (dT)12-18 (Invitrogen) to reverse transcribe polyA+ mRNA. Primer annealing was carried out at $70^{\circ} \mathrm{C}$ for $10 \mathrm{~min}$, before reverse transcriptase was added. Conditions for 


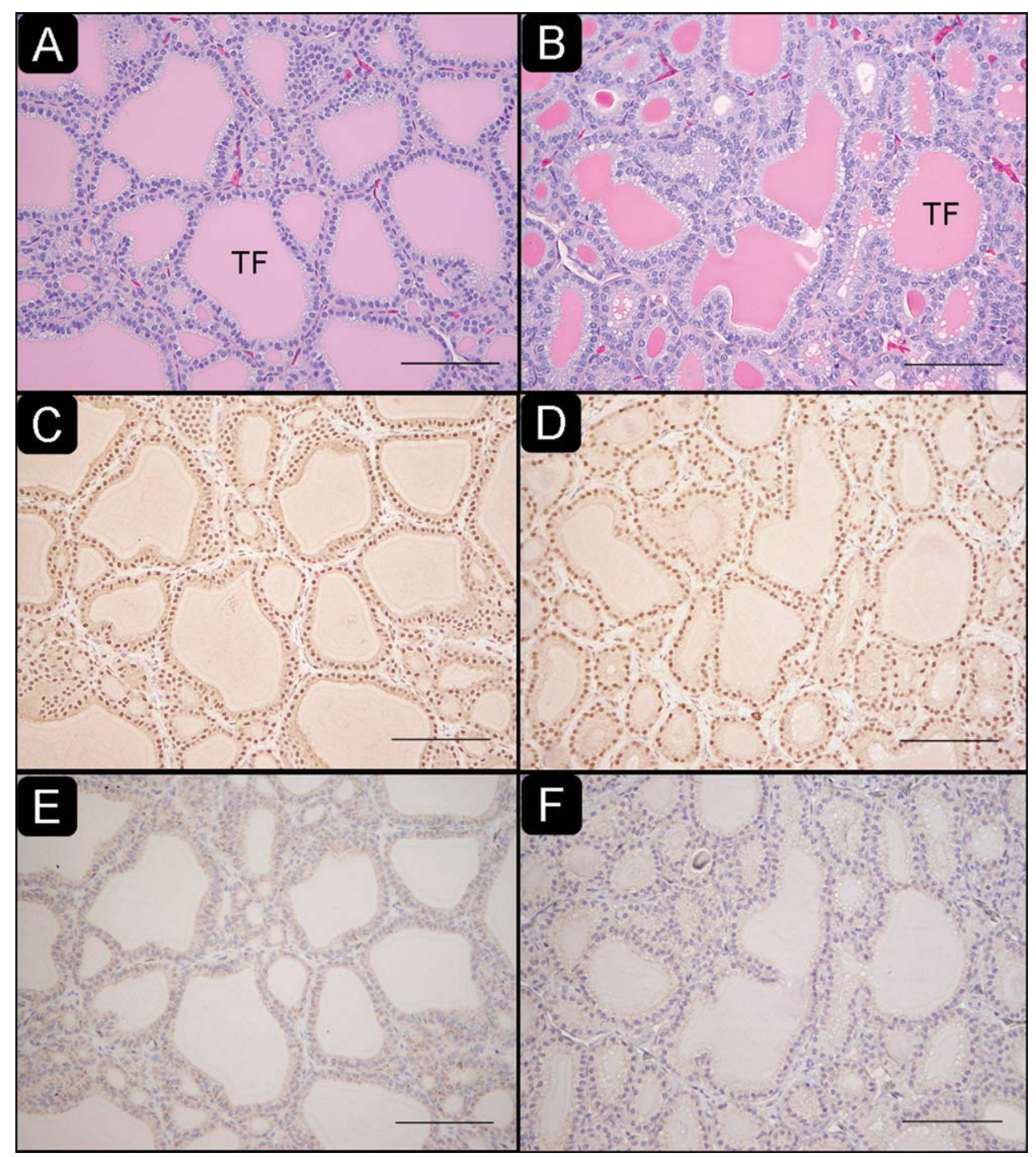

Fig. 1. Photomicrograph of juvenile (A,C,E) and adult (B,D,F) American alligator (A. mississippiensis) thyroid gland tissue. Tissues presented at stained with $\mathrm{H} \& \mathrm{E}(\mathrm{A}, \mathrm{B})$, primary antibody MC-20 for $\mathrm{ER} \alpha(\mathrm{C}, \mathrm{D})$ or the negative control (E,F). Note the extensive positive staining in the nuclei representative of a positive signal for ER $\alpha$ in the thyroid follicle (TF) cells. Scale bar represents $100 \mu \mathrm{m}$.

first-strand synthesis were $42^{\circ} \mathrm{C}$ for $60 \mathrm{~min}$, followed by $10 \mathrm{~min}$ at $70^{\circ} \mathrm{C}$. Primers for Q-PCR were designed from the alligator coding sequences. A sequence also was previously obtained for alligator $\beta$-actin and ribosomal L8 for the purpose of normalization; primers have been designed based on alligator sequences. Quantitative real time-PCR was carried out in a BioRad MyiQ single color real-time PCR detection system according to the manufacturer's protocol, with the exception that $15 \mu \mathrm{l}$ per well was used. Quantitative real time-PCR conditions were $50^{\circ} \mathrm{C}$ for $2 \mathrm{~min}, 95^{\circ} \mathrm{C}$ for $10 \mathrm{~min}$, and 40 cycles at $95^{\circ} \mathrm{C}$ for $15 \mathrm{sec}$, and $60^{\circ} \mathrm{C}$ for $1 \mathrm{~min}$. To normalize data, the mean $\mathrm{Ct}$ (threshold cycle) for ribosomal L8 was used on the mean Ct of the genes of interest $(\mathrm{ER} \alpha, \mathrm{ER} \beta, \mathrm{TR} \alpha, \mathrm{TR} \beta$, and $\mathrm{AR})$. Relative expression counts were calculated using the $2^{-\Delta \Delta \mathrm{Ct}}$ method (Livak and Schmittgen, 2001). Northern analysis was performed using standard techniques to determine quality of the mRNA before Q-PCR; gels were loaded with $20 \mu \mathrm{g}$ total RNA. Labeling of cDNA probes was achieved by random priming (Prime-It II, Stratagene, La Jolla, CA) using $\left(\mathrm{ATP}_{-}{ }^{32} \mathrm{P}\right) \mathrm{dCTP}(\mathrm{SA} 3,000 \mathrm{Ci} /$ mmol; New England Nuclear) according to the manufacturer's protocol.

\section{RESULTS}

\section{Immunohistochemical Localization of ER $\alpha$}

Localization of $\mathrm{ER} \alpha$ was visualized in the thyroid follicle cells using a mammalian polyclonal antibody (Fig. 1). ER $\alpha$ expression was observed at a high level, with the majority of the nuclei of the thyroid follicle cells displaying positive staining for the $\mathrm{ER} \alpha$ antibody at all life stages examined. Using the ratio of IHC-ER $\alpha$ positive cell nuclei to nonpositive nuclei, an ANOVA revealed that sexual dimorphism was not detected in ER $\alpha$ protein expression, as determined by immunohistochemistry, at any of the life stages examined in this study (Fig. 2). Adult, juvenile, and neonate tissue samples were collected at different times of the year, which precluded evaluation of ER $\alpha$ across life stage due to confounding factor of season. 


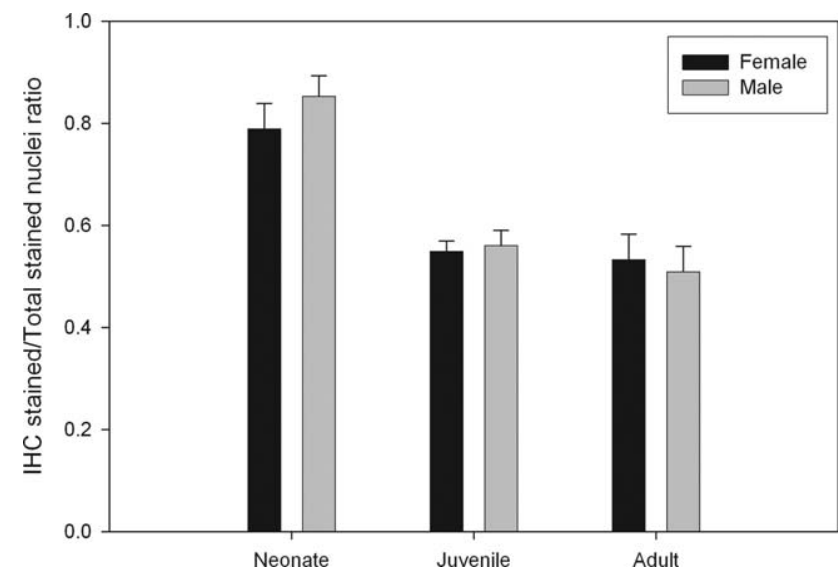

Fig. 2. Mean ratio for immunohistochemistry (IHC) ER $\alpha$ expression (measured by the ratio of IHC ER $\alpha$ positive staining to normal hemotoxylin and eosin staining) in the thyroid follicle at three life stages in the American alligator (A. mississippiensis). Error bars are \pm 1 standard error from the mean. No sexually dimorphic pattern was observed.

\section{Quantitative RT-PCR}

Thyroid tissues from neonatal, juvenile, and adult alligators expressed mRNA for $\mathrm{ER} \alpha$, ER $\beta$, TR $\alpha$, TR $\beta$, and AR. Using a Q-PCR approach, we examined whether a sexually dimorphic pattern existed in the expression of sex steroid hormone receptors or thyroid hormone receptors. No statistically significant differences were observed between male or female thyroid gland mRNA expressions for any of the genes analyzed in this study, although we did observed very high variance in expression of all of the genes studied (Fig. 3). Confounding factor of season precluded analysis of gene expression across life stages.

\section{DISCUSSION}

There is a dearth of literature describing the presence of ERs and ARs in cells of the thyroid from nonmammalian species. The data presented demonstrates that the thyroid of a nonmammalian vertebrate can express both forms of ERs, TRs, and AR throughout its life. Both forms of ER (ER $\alpha$ and ER $\beta$ ) are known to be expressed in the human thyroid gland (Kawabata et al., 2003). Further, we were able to observe that the mRNA for ER $\alpha$ is translated to protein, as we detected its presence in the thyroid follicle cells using an antibody specific for $\mathrm{ER} \alpha$.

When IHC-derived ER $\alpha$ expression in thyroid gland tissues were analyzed, we were unable to detect a sexually dimorphic pattern at any of the three life stages examined. These results are contrary to our initial hypothesis that females would display higher $\mathrm{ER} \alpha$ expression in the thyroid gland. It is important to note that we were count- ing positive nuclei per thyroid follicle and this would be but one measure of potential estrogen activity in a thyroid follicle; that is, an indication of the number of potential cells that could respond to an estrogenic signal. When we quantitatively measured ER mRNA expression for both isoforms of ER, in thyroid gland tissues from males and females at various life stages, no sexual dimorphism was detected in mRNA expression for either $\mathrm{ER} \alpha$ or ER $\beta$. Both of these measurements, IHC and mRNA expression, are but estimates of potential ERs activity in a thyroid follicle and do not preclude that a sexually dimorphic pattern might exist. Recent studies examining the mammalian thyroid gland suggest that ER expression is not sexually dimorphic, but rather, the postligand binding response of ERs to $\mathrm{E}_{2}$ is dimorphic (Correa da Costa et al., 2001; Lima et al., 2006; Marassi et al., 2007). Estrogens exert effects by activation of MAP kinases as well as by binding to ERs.

However, like other vertebrates, there clearly is a sexually dimorphic pattern in hormone expression, as female alligators exhibit elevated plasma concentrations of various estrogens when compared with males at all ages except neonates (Guillette et al., 1994; Guillette et al., 1997; Milnes et al., 2002; Milnes et al., 2005; Moore et al., 2010). As alligators sexually mature, the plasma concentrations of sex steroids increase. We
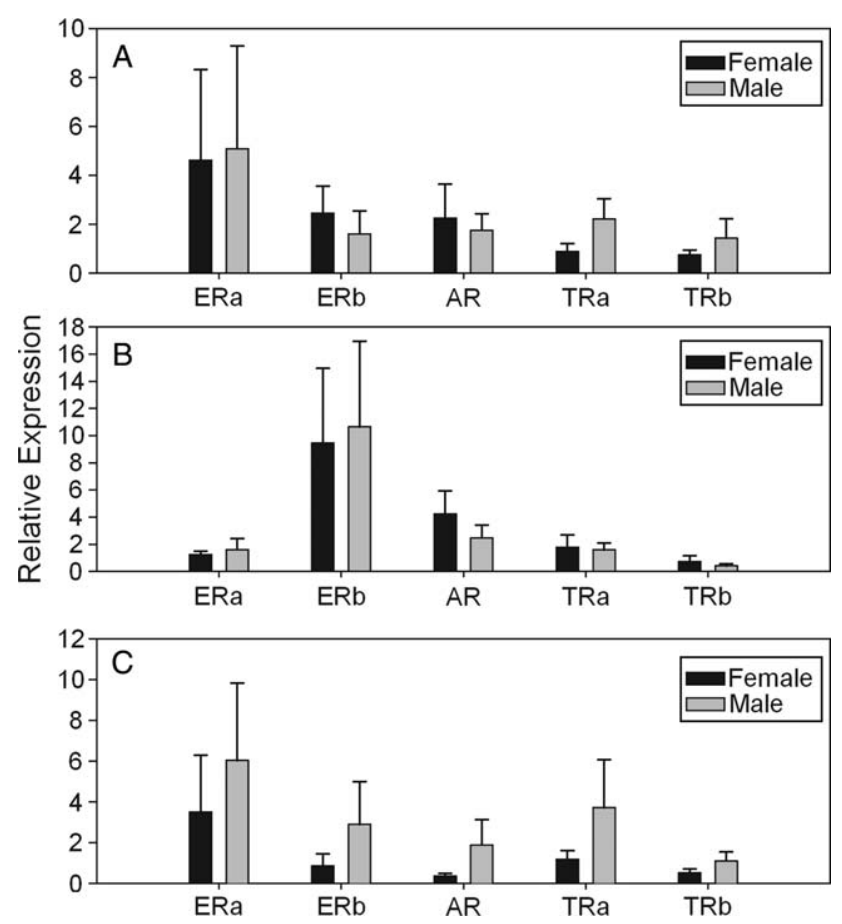

Fig. 3. mRNA gene expression in thyroid gland tissue from neonatal (A), juvenile (B), and adult $(\mathbf{C})$ American alligator $(A$. mississippiensis). Genes were normalized to ribosomal L8 and relative expressions were calculated using the $2^{-\Delta \Delta \mathrm{Ct}}$ method. Error bar represent \pm 1 standard error from mean. No sexual dimorphic patterns were observed. 
hypothesized that, because adults have higher plasma concentration of $\mathrm{E}_{2}$ compared with the other life stages (Guillette and Milnes, 2000; Rooney et al., 2004), the adult alligators would show lower ER $\alpha$ ratios and, therefore, lower ER $\alpha$ expression due to a potential feedback loop that would downregulate the expression of the receptor. Our immunohistochemical data suggests that neonates have a significantly higher ratio of $\mathrm{ER} \alpha \mathrm{com}-$ pared with either the juvenile or adult alligators. The antibodies for ER $\alpha$ were an affinity purified rabbit polyclonal antibody rose against a peptide (12-20 amino acids) mapping between 550 and 599 of the carboxyl-terminus for $\mathrm{ER} \alpha$ of mouse origin. The similarity of $\mathrm{E} / \mathrm{F}$ domain of $\mathrm{ER} \alpha$ between the American alligator and mouse is 86\%. Although both mouse and alligator $\mathrm{ER} \alpha$ display strong sequence homology at the $\mathrm{E} / \mathrm{F}$ domain, caution should be taken when interpreting solely from immunohistochemical results.

The difference between sexes in circulating hormone concentrations, coupled with the active expression of ER in the thyroid, suggests that 1) estrogens likely play an important and largely unstudied role in the regulation of the thyroid of nonmammalian vertebrates, and 2) the thyroid gland could be a target of various ubiquitous environmental contaminants known to function as estrogen, androgen, or thyroid hormone receptor agonists or antagonists (McLachlan, 2001), again an area of research largely unexamined in all vertebrates. Given the growing list of environmental estrogens (Rooney and Guillette, 2000), antiandrogens, and now thyroid hormone receptor antagonists, this should be a growing concern, given the critical role, the thyroid gland plays in metabolism, thermoregulation, growth, nerve function, and reproduction.

Further, we observed that both forms of ER are expressed in the thyroid gland of the American alligators, and previous studies have shown that these receptor isoforms can have different physiological roles in cells. An ER $\alpha$ agonist can play a role in the proliferation of thyroid cancer cell growth, whereas an ER $\beta$ agonist can reduce proliferation of cancer cells (Ceresini et al., 2006; Cho et al., 2007; Chen et al., 2008).

One confounding factor in comparing the life stages should be noted; although we have demonstrated that ER $\alpha$ protein and mRNA for ER $\alpha$ and ER $\beta$ are expressed in the thyroid gland, the available tissues from each life stage came at different times in the year. Tissues from neonatal alligators were obtained immediately after hatching in late August, whereas those from juveniles were obtained during mid-summer (June) or during September for adults. We note this, as a previous study examining the tissue distribution of $\mathrm{ER} \alpha$ in alligators done in collaboration with our group, observed no ER mRNA expression for juvenile alligator thyroid gland tissue (Helbing et al., 2006) in contrast to our findings. Interestingly, the animals in that study were collected from the wild (Lake Woodruff NWR, Florida) in September, the same location from which we obtained the animals for this study in June. Further, the animals used in the present study are approximately $20 \mathrm{~cm}$ longer in snout-vent length, suggesting that they are approximately 1-2 years older (Milnes et al., 2002) than those examined by Helbing et al. (2006). These data suggest possible life stage differences, but that is unlikely given that we observed ER $\alpha$ mRNA expression in the thyroid gland tissue of neonates, juveniles, and adults. We suggest that possible seasonal variation in the expression of ERs in the thyroid is more likely and this needs to be tested, although the protected status of this animal could preclude monthly sampling for such a test.

The alligator thyroid gland expresses AR mRNA. Both adult and neonatal stages displayed significantly lower AR mRNA expression levels when compared with juveniles. Juvenile alligators of the size we examined in this study display seasonal variation in plasma testosterone concentrations (Rooney et al., 2004) and respond dramatically with elevated androgen production when stimulated with FSH (Edwards et al., 2004). Further, juvenile alligators appear to display a multiyear period of puberty (Rooney et al., 2004), and these data suggest a hypothesis that AR function during the juvenile life stage could play a role during peripubertal maturation of the thyroid gland. Androgens have been suggested to increase thyroid function by up-regulating expression of genes such as thyroperoxidase and thyroglobulin (Correa da Costa et al., 2001). Future studies need to test this hypothesis.

This study has shown that mRNA for both forms of ER, both forms of TR and AR are found on the thyroid gland of the American alligator (A. mississippiensis). We did not observe sexual dimorphism in the mRNA expression of these genes in the thyroid gland nor did we note an obvious sexually dimorphic expression pattern for ER $\alpha$ based on immunohistochemical visualization. However, the presence of sex steroid hormone receptors provides a mechanism by which gonadal steroid hormones, or contaminants mimicking these ligands, could influence thyroid gland development and function.

\section{ACKNOWLEDGMENTS}

The authors thank Allen R. Woodward and the Florida Fish and Wildlife Conservation Commission for their aid in capturing and restraining alligators, for facility and equipment support. The authors also thank Teresa Bryan, Mark Gunderson, Satomi Kohno, Mathew Milnes and Brandon Moore for aid in the field. 


\section{LITERATURE CITED}

Arain SA, Shah MH, Meo SA, Jamal Q. 2003. Estrogen receptors in human thyroid gland-An immunohistological study. Saudi Med J 24:174-178.

Arambepola NK, Bunick D, Cooke PS. 1998. Thyroid hormone effects on androgen receptor messenger RNA expression in rat Sertoli and peritubular cells. Endocrinology 156:43-50.

Banu SK, Govindarajulu P, Aruldhas MM. 2002. Testosterone and estradiol up-regulate androgen and estrogen receptors in immature and adult rat thyroid glands in vivo. Steroids 67:1007-1014.

Bermudez DS, Milnes MR, Bryan TA, Gunderson MP, Tubbs C, Woodward A, Guillette LJJ. 2005. Seasonal variation in plasma thyroxine concentrations in juvenile alligators (Alligators mississippiensis) from three Florida lakes. Comp Biochem Phys A 141:8-14.

Bernal J, Guadano-Ferraz A, Morte B. 2003. Perspectives in the study of thyroid hormone action on brain development and function. Thyroid 13:1005-1012.

Cayrou C, Denver RJ, Puymirat J. 2002. Suppression of the basic transcription element-binding protein in brain neural cultures inhibits thyroid hormone-induced neurite branching. Endocrinology 143:2242-2249.

Ceresini G, Morganti S, Graiani V, Saccani M, Milli B, Usberti E, Valenti G, Ceda GP, Corcione L. 2006. Estrogen receptor(ER)-beta, but not ER-alpha, is present in thyroid vessel: Immunohistochemical evaluations in multinodular goiter and papillary thyroid carcinoma. Thyroid 16:1215-1220.

Chen GG, Vlantis AC, Zeng Q, van Hasselt CA. 2008. Regulation of cell growth by estrogen signaling and potential targets in thyroid cancer. Curr Cancer Drug Targets 8:367-377.

Cho MA, Lee MK, Nam KH, Chung WY, Park CS, Lee JH, Nohl T, Yang WI, Rhee Y, Lim SK, Lee HC, Lee EJ. 2007. Expression and role of estrogen receptor alpha and beta in medullary thyroid carcinoma: Different roles in cancer and apoptosis. J Endocrinol 195:255-263.

Cooke PS, Hess RA, Porcelli J, Meisami E. 1991. Increase sperm production in adult rats after transient neonatal hypothyroidism. Endocrinology 129:244-248.

Correa da Costa VM, Moreira DG, Rosenthal D. 2001. Thyroid function and aging: Gender-related differences. J Endocrinol 171:193-198.

Edwards TM, Gunderson MP, Milnes MR, Guillette LJ Jr. 2004. Gonadotropin-induced testosterone response in peripubertal male alligators. Gen Comp Endocr 135:372-380.

Fujimoto N, Sakai Y, Ito A. 1992. Increase in estrogen-receptor levels in MNU induced thyroid-tumors in LE rats. Carcinogenesis 13:1315-1318.

Giani C, Campani D, Denegri F, Martini L, Fabbri R, Bonacci R, Ciancia EM, Gigliotti A, Fierabracci P, Pinchera A. 1993. Interferance of thyroperoxidase on immuno-cytochemical determination of steroid-receptors in thyroid tissue. J Endocrinol Invest 16:37-43.

Guillette LJ, Gross TS, Masson GR, Matter JM, Percival HF, Woodward AR. 1994. Developmental Abnormalities of the Gonad and Abnormal Sex-Hormone Concentrations in Juvenile Alligators from Contaminated and Control Lakes in Florida. Environ Health Persp 102:680-688.

Guillette LJ Jr, Milnes MR. 2000. Recent observations on the reproductive physiology and toxicology of crocodilians. In: Grigg GC, Seebacher F, Franklin CE, editors. Crocodilian Biology and Evolution. Chipping Norton: Surrey Beatty \& Sons. pp 199-213.

Guillette LJ Jr, Woodward A, Crain DA, Masson GR, Palmer BD, Cox C, You-Xiang Q, Orlando EF. 1997. The reproductive cycle of the female American alligator (Alligator mississippiensis). Gen Comp Endocr 108:87-101.

Helbing CC, Crump K, Bailey CM, Kohno S, Veldhoen N, Bryan TA, Bermudez DS, Guillette LJ Jr. 2006. Isolation of the alli- gator (Alligator mississippiensis) thyroid hormone receptor $\alpha$ and $\beta$ transcripts and their responsiveness to thyroid stimulating hormone. Gen Comp Endocr 149:141-150.

Katsu Y, Bermudez DS, Braun EL, Helbing C, Miyagawa S, Gunderson MP, Kohno S, Bryan TA, Guillette L. J. J, Iguchi T. 2004. Molecular cloning of the estrogen and progesterone receptors of the American alligator. Gen Comp Endocr 136:122-133.

Kawabata W, Suzuki T, Moriya T, Fujimori K, Naganuma H, Inoue S, Kinouchi Y, Kameyama K, Takami H, Shimosegawa T, Sasano H. 2003. Estrogen receptors $(\alpha$ and $\beta)$ and $17 \beta-$ hydroxysteroid dehydrogenase type 1 and 2 in thyroid disorders: Possible in situ estrogen synthesis and actions. Mod Pathol 16:437-444.

Lima LP, Barros IA, Lisboa PC, Araujo RL, Silva ACM, Rosenthal D, Ferreira ACF, Carvalho DP. 2006. Estrogen effects on thyroid iodide uptake and thyroperoxidase activity in normal and ovariectomized rats. Steroids 71:653-659.

Livak KJ, Schmittgen TD. 2001. Analysis of relative gene expression data using real-time quantitative PCR and the 2delta delta Ct method. Methods 25:402-408.

Madej A, Persson E, Lundh T, Ridderstrale Y. 2002. Thyroid gland function in ovariectomized ewes exposed to phytoestrogens. J Chromatogr B 777:281-287.

Manole D, Schildknecht B, Gosnell B, Adams E, Derwahl M. 2001. Estrogen promotes growth of human thyroid tumor cells by different molecular mechanisms. J Clin Endocr Metab 86:1072-1077.

Marassi MP, Fortunato RS, Matos da Silva AC, Pereira VS, Carvalho DP, Rosenthal D, Correa da Costa VM. 2007. Sexual dimorphism in thyroid function and type 1 iodothyronine deiodiase activity in pre-pubertal and adult rats. J Endocrinol 192:121-130.

McKenna NJ, O’Malley BW. 2001. Nuclear receptors, coregulators, ligands, and selective receptor modulators: Making sense of the patchwork quilt. Ann N Y Acad Sci 949:3-5.

McLachlan JA. 2001. Environmental signaling: What embryos and evolution teach us about endocrine disrupting chemicals. Endocr Rev 22:319-341.

Milnes MR, Bermudez DS, Bryan TA, Gunderson MP, Guillette LJ. 2005. Altered neonatal development and endocrine function in Alligator mississippiensis associated with a contaminated environment. Biol Reprod 73:1004-1010.

Milnes MR, Woodward AR, Rooney AA, Guillette LJ. 2002. Plasma steroid concentrations in relation to size and age in juvenile alligators from two Florida lakes. Comp Biochem Physiol A Mol Integr Physiol 131:923-930.

Moore BC, Milnes MR, Kohno S, Katsu Y, Iguchi T, Guillette LJ. 2010. Influences of sex, incubation temperature, and environmental quality on gonadal estrogen and androgen receptor messenger RNA expression in Juvenile American Alligators (Alligator mississippiensis). Biol Reprod 82:194-201.

Norris DO. 2007. Vertebrate Endocrinology. San Diego: Academic Press.

Paterson CM, Greenlee R, Adam Jones D. 1999. Thyroid cancer in Wales 1985-1996: A cancer registry-based study. Clin Oncol 11:245-251.

Rooney AA, Crain DA, Woodward A, Guillette LJ Jr. 2004. Seasonal variation in plasma sex steroid concentrations in juvenile American alligators. Gen Comp Endocr 135:25-34.

Rooney AA, Guillette LJ Jr. 2000. Contaminant interactions with steroid receptors: Evidence for receptor binding. In: Guillette LJ Jr, Crain DA, editors. Endocrine Disrupting Contaminants: An Evolutionary Perspective. Philadelphia: Francis and Taylor. pp82-125.

Styne DM. 1998. Fetal growth. Clin Perinatol 25:917-938.

Tahboub R, Arafah BM. 2009. Sex steroids and the thyroid. Best Pract Res Clin Endocrinol Metab 23:769-780. 